\title{
In silico screening of natural products targeting chorismate synthase
}

\section{Detección in silico de productos naturales dirigidos a la} corismato sintasa
Author:

Mohammed Zaghlool Al-Khayyat ${ }^{1}$

SCIENTIFIC RESEARCH

How to cite this paper:

Al-Khayyat M, In Silico screening of natural products targeting chorismate synthase. Innovaciencia. 2019; 7 (1): 1-13.

http://dx.doi.org/10.15649/2346075X.505

Reception date:

Received: 20 January 2019

Accepted: 16 May 2019

Published: 25 October 2019

Keywords:

Amentoflavone; Docking; Homology modeling; Pharmacokinetics.

\section{ABSTRACT}

Introduction: Chorismate synthase catalyzes the final step in shikimate acid pathway involved in synthesis of aromatic compounds in bacteria. This enzyme can be a possible molecular target for design of antibiotics. Materials and Methods: Homology modeling and molecular docking were performed to screen about one hundred natural compounds in order to find inhibitors of enzymes as a possible new target. A model was built by SWISS-MODEL and its quality was assessed by ERRAT, ProSA, Rampage and MolProbity servers. Docking experiments were performed and pharmacokinetics and toxicities were studied by admetSAR. Results: The predicted model was reliable to be used in docking experiments. Amentoflavone had the highest binding affinity of $-10.0 \mathrm{Kcal} / \mathrm{mol}$. Probabilities indicated that rotenone may inhibit P-glycoprotein I, hinokiflavone and silybin may inhibit P-glycoprotein II, while taspine acts on both types of P-glycoproteins. Amentofalavone, hinokiflavone, rotenone and silybin have a probability of inhibiting cytochromes that are involved in oxidation stage of metabolism. Conclusions: These compounds had binding affinities towards FMN binding site of the enzyme model and may be considered in the research for new antibacterial agents but only when their drug interactions are fully investigated.

1 Biology Department, College of Education for Pure Sciences, University of Mosul. mzsaeed19@hotmail.com. 


\section{INTRODUCCTION}

Staphylococcus aureus is a Gram positive bacterium capable of causing infections in human ranging from superficial lesions such as cutaneous and subcutaneous abscesses to deep infections involving bones, lung as well as toxic shock syndrome ${ }^{(1,2)}$. This is due to its ability to invade and colonize tissues through expression of numerous virulence factors like exofoliative toxins, haemolysins, leukocidins, protein A and clumping factor ${ }^{(1,3)}$.

In $1961, S$. aureus developed resistance to the antibiotic methicillin and later on, to other members of penicillin group, the $\beta$-lactams. This methicillin resistant $S$. aureus (MRSA) strains acquired a mec $A$ gene encoding to an altered penicillin binding protein, PBP2a which is less susceptible to $\beta$-lactams antibiotics including methicillin ${ }^{(4)}$. In Iraq, a study carried out by Al-Dahbi and Al-Mathkhury ${ }^{(5)}$ on nasal isolates of $S$. aureus in a hospital found that MRSA constitutes about $94.3 \%$. All the one hundred and six isolates were resistant to penicillin $G$ and $94.3 \%$ of them were resistant to cefoxitin. These isolates had also $29.2-50 \%$ of resistance to ciprofloxacin, gentamicin, tetracycline, erythromycin and co-trimoxazole.

Due to antibiotic resistance, alternative targets are being considered upon which new antibiotics could be designed. Dias et al., ${ }^{(6)}$ suggested that chorismate synthase may be a target. This enzyme is a component of the shikimic acid pathway which is responsible for the biosynthesis of aromatic amino acids in bacteria but not in human. Chorismate synthase catalyzes the formation of chorismate from 5-enolpyruvyl shikimate-3-phosphate using flavin mononucleotide (FMN) as a cofactor ${ }^{(7,8)}$. In this study, homology modeling and molecular docking are carried out on chorismate synthase of $S$. aureus subsp.

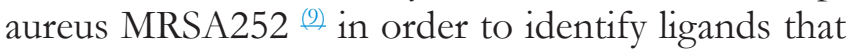
are capable of binding the active site of the enzyme where FMN binds as a preliminary step in screening for enzyme inhibitors.

\section{MATERIALS AND METHODS}

\section{Sequence retrieval}

Amino acid sequence of chorismate synthase of $S$. aureus subsp. aureus MRSA252 $\stackrel{(2)}{ }$ was obtained from
GeneBank database having ID: CAG40475.1, which can be accessed at http://www.ncbi.nlm.nih.gov/ protein/cag40475.1.

\section{Binding site prediction}

Binding site was predicted by (a) RaptorX ${ }^{(10)}$ maintained by Xu Group at University of Chicago available at: (raptorx.uchicago.edu). (b) GalaxyWEB web server for protein structure prediction, refinement and related methods at Computational Biology Lab., Department of Chemistry, Seoul University. The server uses LIGPLOT ${ }^{(11)}$. This binding prediction tool can be accessed at: (http://galaxy.seoklab.org/ cgi-bin/submit.cgi?type $=$ SITE) .

\section{Homology modeling}

The 3 dimensional structure of the enzyme, chain A was built by SWISS-MODEL $\stackrel{(12)}{2}$ maintained by Protein Structure Bioinformatics Group at Swiss Institute of Bioinformatics and Biozentrum, University of Basel, Basel, Switzerland. It is available at (http:/ / swissmodel.expasy.org).

\section{Quality assessment of the model}

The accuracy of the model was assessed by four

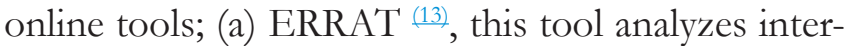
action of non-bound heavy atoms and comparing it with refined structures, available at (http://servicesn.mbi.ucla.edu/ERRAT/) at Molecular Biology Institute, University of California, Los Angeles. (b) PROSA ${ }^{(14)}$, to determine if the protein fold lies within the range of experimentally determined protein structures accessed at (https://prosa.services.came. sbg.ac.at/prosa.php) The site is maintained by Cen ter of Applied Molecular Engineering, Department of Biosciences, University of Salzburg. (c) Ramachandran plot analysis by RAMPAGE ${ }^{(15)}$. The site is maintained by Crystallography and Bioinformatics Group at Department of Biochemistry, School of Biological Sciences, University of Cambridge, available at: (http://mordred.bioc.cam.ac.uk/ rapper/ rampage.php). (d) MolProbity structure validation $\stackrel{(16)}{\text { (1) }}$ from Department of Biochemistry, School of Medicine, Duke University. The software can be accessed at: (http://molprobity.biochem.duke.edu/).

\section{Ligand selection}

The chemical structures of the control, Flavin mononucleotide $(\mathrm{FMN})$ and one hundred natural products

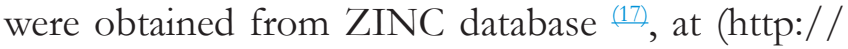


zinc.docking.org/). This database also provides the molecular properties; mass, $\mathrm{H}$-bond donors, $\mathrm{H}$-bond acceptors and polar surface area.

\section{Molecular docking}

Molecular docking was performed by AutoDock Vina (18) designed by Oleg Trott from Molecular graphics Laboratory at the Scripps Research Institute, La Jolla, California. The Autogrid tool was employed to pre-calculate a grid. This grid has a size of $66 \times 66 \times 66$ and a box center of $-8.118,1.819$ and 10.049 for $x, y$ and $z$, respectively. Rigid protein-ligand docking was performed by Hex 8.0.0 using settings: grid dimension $=0.6$, docking solutions $=$ 100 , an initial steric scan at $\mathrm{N}=16$, a final search at $\mathrm{N}=26$, receptor and ligand range 180 degrees (Ritchie and Venkatraman, 2010). Interactions between ligand and the enzyme model were visualized by LIGPLOT+ $\stackrel{(11)}{~}$.

\section{Pharmacologic properties of the compounds}

The pharmacokinetics and toxicity profiles (ADMET) of the compounds were predicted by admetSAR (19) at (http://lmmd.ecust.edu.cn/admetsar1). The computed parameters were: (1) human intestinal absorption (HIA), (2) blood-brain barrier (BBB) penetration, (3) human colon adenocarcinoma (Caco-2) permeability, (4) plasma glycoprotein (P-gp) substrate and inhibition probabilities, (5) renal organic cationic transporter protein (OCT2) inhibition, (6)
Cytochromes (CYP P450), substrate and inhibition probabilities. Toxicities were predicted by (1) carcinogenic activity and (2) acute rat toxicity (ART).

\section{RESULTS AND DISCUSSION}

The three dimensional structure of chorismate synthase, chain A was built by SWISS-MODEL based on the template of Steptococcus pneumoniae serotype 4, PDB ID: 1xqo.1.A which had a resolution of $2.00 \mathrm{~A}^{\circ}$ with a sequence similarity of 0.45 . Figure 1 shows the model. Maclean and Ali ${ }^{(20)}$ solved the $\mathrm{X}$-ray structure of chorismate synthase of $S$. pneumoniae and found that (a) it is a tetramer of 2 dimer subunits, (b) $\mathrm{Thr}^{315}$ or sometimes Ser is a conserved amino acid in the enzyme structure, (c) The amino acid His ${ }^{110}$ forms Hydrogen bonding with $\mathrm{O}_{2}$ of FMN, (d) the hydrophobic interactions of $\mathrm{Ala}^{342}, \mathrm{Ala}^{345}$, $\mathrm{Ala}^{346}, \mathrm{Ile}^{313}, \mathrm{Met}^{310}$ mediates flexibility required to accommodate FMN molecule, and (e) $\mathrm{O}_{2}$ of FMN also forms coordinate bonding with the side chain of $A s n^{251}$. Binding site prediction by RaptorX server for FMN revealed the following amino acid residues of the model: $\mathrm{Arg}^{45}, \mathrm{Gly}^{111}$, $\mathrm{His}^{112}, \mathrm{Ala}^{135}, \mathrm{Ile}^{250}, \mathrm{Asn}^{251}$, $\mathrm{Ala}^{252}, \mathrm{Met}^{310}, \mathrm{Lys}^{311}, \mathrm{Ile}^{313}, \mathrm{Pro}^{314}, \mathrm{Thr}^{315}, \mathrm{Ala}^{342}, \mathrm{Ala}^{345}$ and $\mathrm{Ala}^{346}$, while GalaxyWEB server predicted that FMN forms $\mathrm{H}$ bond with His122 and hydrophobic interactions with $\mathrm{Arg}^{39}, \mathrm{Ala}^{135}, \mathrm{Il}^{250}, \mathrm{Asn}^{251}, \mathrm{Met}^{310}$, $\mathrm{Ile}^{313}, \mathrm{Pro}^{314}, \mathrm{Ala}^{342}$ and $\mathrm{Ala}^{345}$.

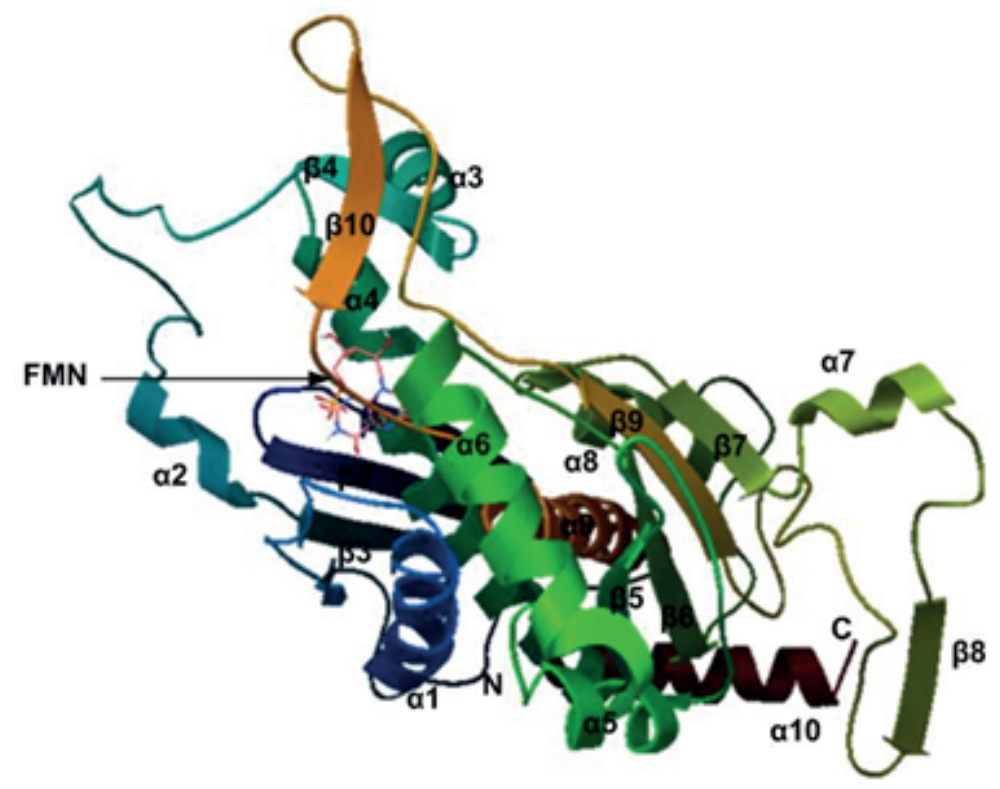

Figure 1. The Three dimensional structure of Chorismate synthase as predicted by SWISS-MODEL. Falavin mononucleotide is shown in its binding site. Visualized by Python Molecular Viewer, Sanner ${ }^{(21)}$. 
The model was evaluated by four on line methods. It has an overall quality of $94.7 \%$ in ERRAT (Figure 2). In ProSA, the model has a Z-score of -9.19; hence, it lies within the range of $\mathrm{X}$-ray experimentally solved structures (Figure 3). In Ramachandran plot analysis (Figure 4), the number of residues in favored region was $367(95.1 \%)$ and the number of the residues in allowed region was $16(4.1 \%)$, but
$3(0.8 \%)$ of residues were in the outlier region. Normally, it is expected that $98 \%$ of the residues should lie in the favored region and about $2.0 \%$ should be in the allowed region. However, MolProbity server indicates that $364(94.3 \%)$ of the residues are in $\mathrm{fa}-$ vored regions and only 4 are outliers (Table 1). The model has good quality since more than $90 \%$ of the residues lie in the favored region $\stackrel{(22)}{2}$.

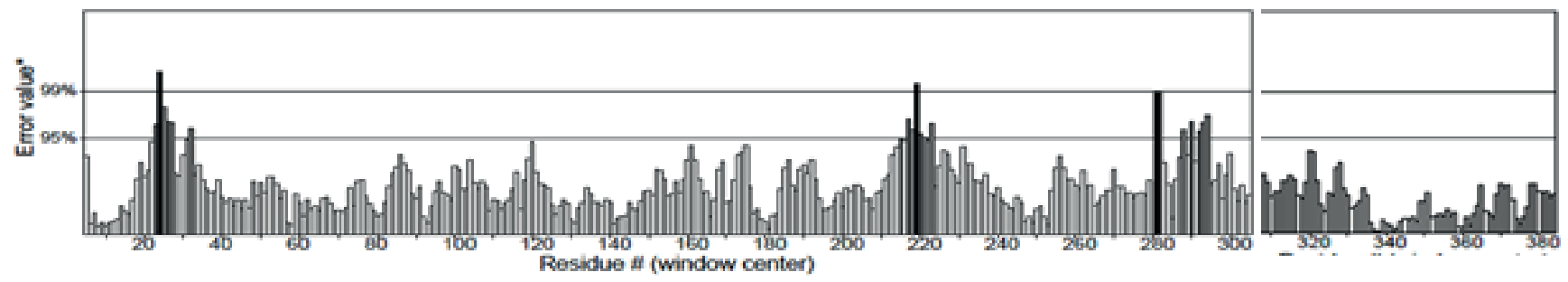

Figure 2. ERRAT analysis of the model. Black bars represent misfolded regions. On the error axis the two lines indicate the confidence in which it is possible to reject regions.

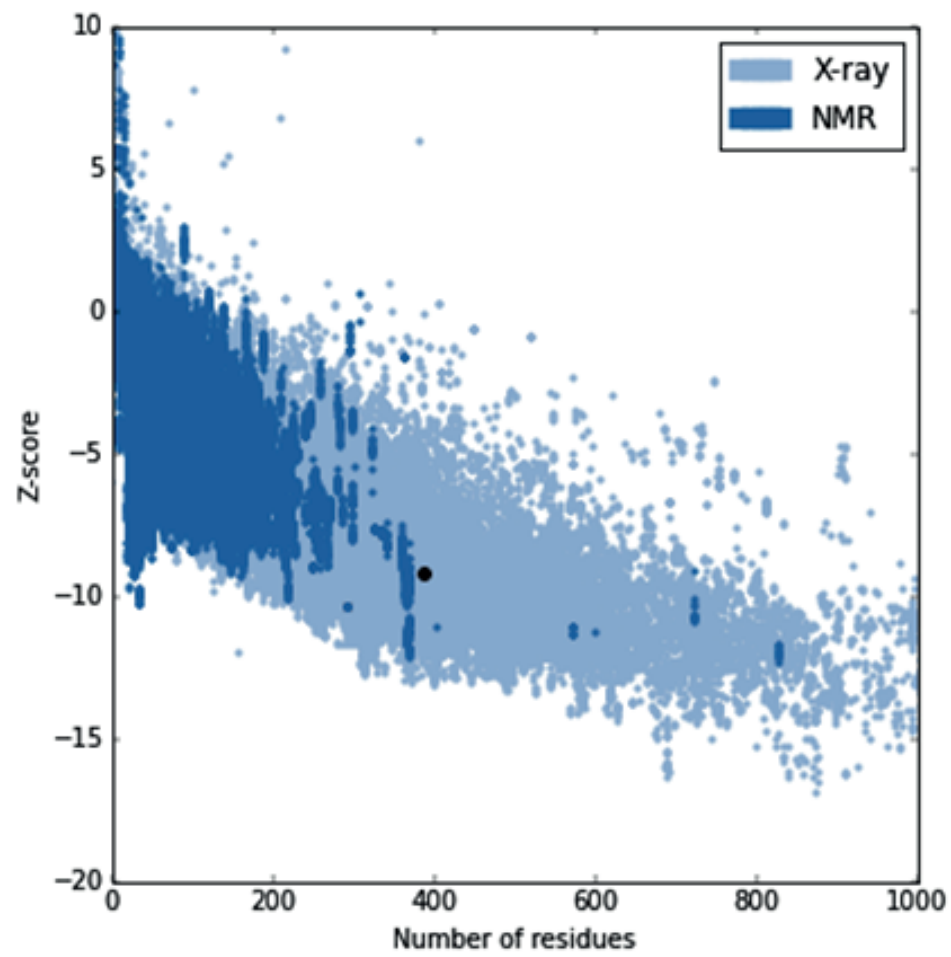

Figure 3. ProSA prediction of the model (black dot) which lies within the normal range of X-ray determined experimental structures. 


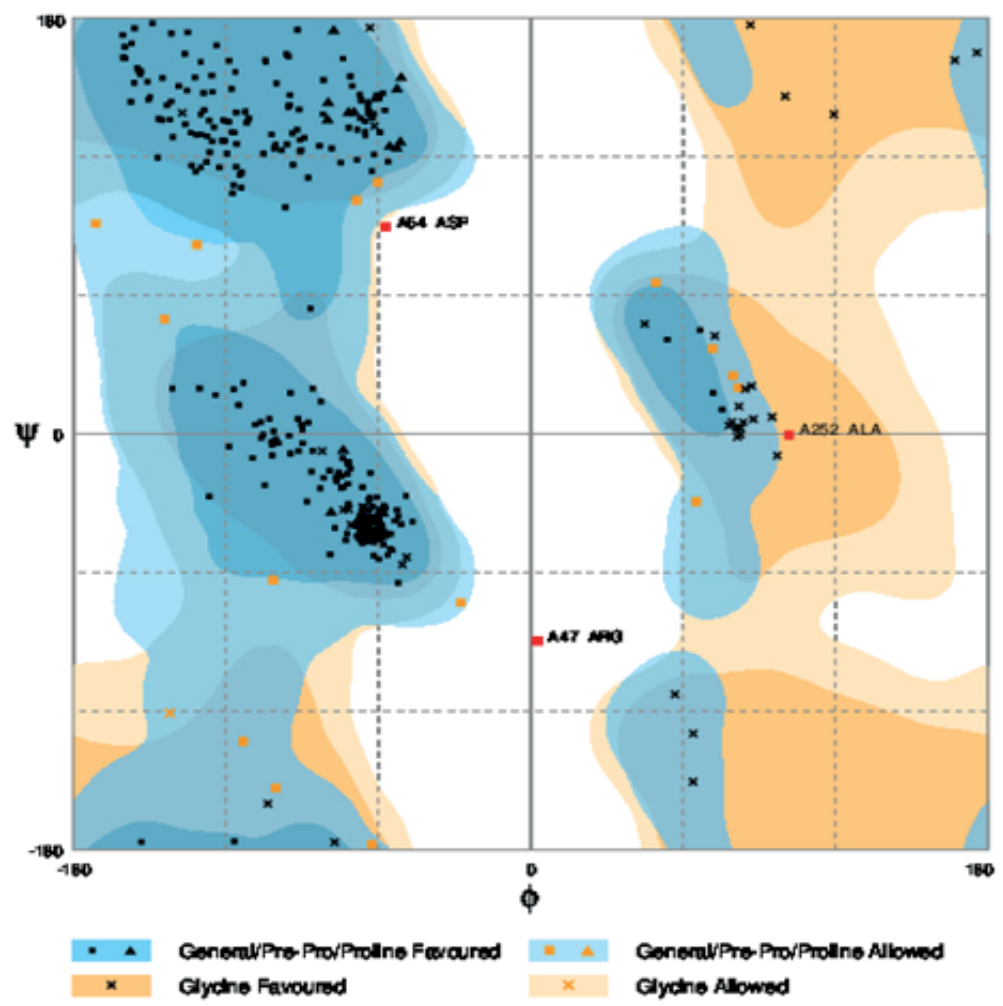

Figure 4. Ramachandran plot of the model using Rampage. Amino acid residues of the model that lie in the disallowed regions (outliers) are marked by red squares.

Table 1. Structure validation by Molprobity server

\begin{tabular}{ccccc}
\hline & Poor rotamers & 9 & $2.76 \%$ & Goal: $<0.3 \%$ \\
& Favored rotamers & 299 & $91.72 \%$ & Goal: $>98 \%$ \\
Protein & Ramachandran outliers & 4 & $1.04 \%$ & Goal: $<0.05 \%$ \\
Reometry & Ramachandran favored & 364 & $94.30 \%$ & Goal: $>98 \%$ \\
& C $\beta$ deviations $>0.25 \AA$ & 2 & $0.57 \%$ & Goal: 0 \\
& Bad bonds: & $0 / 3061$ & $0.00 \%$ & Goal: $0 \%$ \\
& Bad angles: & $27 / 4126$ & $0.65 \%$ & Goal: $<0.1 \%$ \\
\hline \multirow{2}{*}{ Peptide Omegas } & Cis Prolines: & $0 / 13$ & $0.00 \%$ & Expected: $\leq 1$ per chain, or $\leq 5 \%$ \\
& Cis nonProlines: & $1 / 374$ & $0.27 \%$ & Goal: $<0.05 \%$ \\
\hline
\end{tabular}

Molecular docking was performed using AutoDock Vina for one hundred natural products and the highest ten that had binding affinities more than FMN are presented in Table 2 with their interactions. Figure 5 shows the interactions with FMN, while Figure 6 shows the Hydrogen bonding and hydrophobic interactions between amentoflavone and residues of the predicted model. Amentoflavone forms interactions with $\mathrm{Arg}^{39}, \mathrm{Ala}^{135}, \mathrm{Asn}^{251}, \mathrm{Ile}^{313}, \mathrm{Thr}^{315}, \mathrm{Ala}^{342}$ and $\mathrm{Ala}^{345}$ that are also predicted as components of the binding residues by RaptorX and GalaxyWEB.
However, when redocked by Hex 8.0.0 which uses another method of estimating docking scores, only amentoflavone, hinokiflavone, apocynin A and vicenin had docking scores higher than FMN, the control.

Figure 7 illustrates the chemical structures of the best ten ligands, while their physiochemical properties are presented in Table 3 . Kelder et al., ${ }^{(23)}$ concluded that a drug should have a polar surface area (PSA) of $120 \mathrm{~A}^{\circ 2}$ or less but require a PSA of $60-70$ 
$\mathrm{A}^{02}$ to cross the blood brain barrier and have an action on the brain. Good oral absorption occurs when the molecular weight of a drug candidate is in the range 150-550 and $\log \mathrm{P}$ values between 0-3 $\frac{(24)}{4}$. Rutin and vicenin have their molecular weights higher than 550. Four compounds only had their $\log \mathrm{P}$ values in the range of $0-3$. These are scutellarin, apocynin $\mathrm{A}$, silybin and taspine. Lipinski et al., $\stackrel{(25)}{\longrightarrow}$ proposed that a drug will be poorly absorbed when its molecular weight $>500, \log \mathrm{P}>5, \mathrm{H}$-bond donors $>5$ and H-bond acceptors $>10$; however, antifungals and antibacterial agents seem that do not obey this rule and also those classes of drugs that are substrate for drug transporters inside human body.

Table 2. Molecular docking of the model with natural products

\begin{tabular}{|c|c|c|c|c|}
\hline \multirow[b]{2}{*}{ Compound } & \multirow{2}{*}{$\begin{array}{l}\text { Binding affinity } \\
\text { (Kcal/mol) by } \\
\text { AutoDock Vina }\end{array}$} & \multicolumn{2}{|c|}{ Residues of the model forming } & \multirow{2}{*}{$\begin{array}{l}\text { Total energy } \\
\text { (Kcal/mol) } \\
\text { by Hex } 8.0 .0\end{array}$} \\
\hline & & Hydrogen bonds (length in $A^{\circ}$ ) & $\begin{array}{l}\text { Hydrophobic } \\
\text { interactions }\end{array}$ & \\
\hline FMN (control) & -8.0 & $\begin{array}{l}\operatorname{Ser}^{9}(2.84,3.17), \operatorname{Arg}^{45}(2.90) \\
\operatorname{Arg}^{109}(2.70), \operatorname{Ser}^{134}(3.06)\end{array}$ & $\begin{array}{l}\operatorname{Arg}^{47}, \operatorname{Arg}^{48}, \mathrm{His}^{112}, \mathrm{Ala}^{135} \\
\operatorname{Arg}^{136}, \mathrm{Ile}^{313}, \mathrm{Thr}^{315}, \mathrm{Asp}^{339}\end{array}$ & -337.60 \\
\hline Amentoflavone & -10.0 & $\begin{array}{c}\operatorname{Ser}^{9}(3.20), \operatorname{Arg}^{39}(2.82,3.05) \\
\operatorname{Asn}^{251}(2.70), \operatorname{Thr}^{315}(2.70), \operatorname{Ser}^{338}(3.15)\end{array}$ & $\begin{array}{l}\operatorname{His}^{10}, \mathrm{Arg}^{45}, \mathrm{Arg}^{48}, \mathrm{Met}^{49}, \\
\operatorname{Arg}^{109}, \mathrm{Leu}^{130}, \mathrm{Ser}^{134}, \mathrm{Ala}^{135}, \\
\operatorname{Arg}^{136}, \mathrm{Ala}^{252}, \mathrm{Met}^{310}, \mathrm{Ile}^{313}, \\
\quad \mathrm{Asp}^{339}, \mathrm{Ala}^{342}, \mathrm{Ala}^{345}\end{array}$ & -351.04 \\
\hline Scutellarin & -9.4 & $\begin{array}{l}\operatorname{Arg}^{45}(3.24), \operatorname{Ser}^{9}(2.76,2.95) \\
\operatorname{Ser}^{134}(3.04), \operatorname{Asp}^{339}(2.84)\end{array}$ & $\begin{array}{l}\operatorname{Arg}^{48}, \mathrm{Met}^{49}, \mathrm{His}^{112}, \mathrm{Ser}^{133} \\
\text { Ala } \\
\mathrm{Ala}^{135}, \mathrm{Arg}^{136}, \mathrm{Ale}^{313}, \mathrm{Pro}^{251}, \mathrm{Ala}^{342}\end{array}$ & -303.62 \\
\hline Rutin & -9.3 & $\begin{array}{c}\operatorname{Ser}^{9}(2.79), \operatorname{Arg}^{45}(2.58,2.97), \operatorname{Arg}^{48}(3.30) \\
\operatorname{Ser}^{134}(3.16), \operatorname{Thr}^{138}(3.17), \operatorname{Asn}^{251}(3.08) \\
\operatorname{Thr}^{315}(2.52), \operatorname{Asp}^{339}(3.23)\end{array}$ & $\begin{array}{c}\text { Arg }{ }^{47}, \mathrm{Met}^{49}, \mathrm{Ala}^{135}, \mathrm{Arg}^{136}, \\
\mathrm{Ile}^{250}, \mathrm{Phe}^{253}, \mathrm{Ile}^{313}, \mathrm{Arg}^{337}, \\
\mathrm{Ser}^{338}, \mathrm{Ala}^{342}, \mathrm{Ala}^{345} \\
\mathrm{Ala}^{346}, \mathrm{Val}^{349}\end{array}$ & -326.52 \\
\hline Hinokiflavone & -9.1 & $\mathrm{Ala}^{252}(3.29,2.88)$ & $\begin{array}{c}\text { Arg } 45, \mathrm{His}^{112}, \mathrm{Ala}^{113}, \mathrm{Ser}^{133}, \\
\mathrm{Ala}^{135}, \mathrm{Val}^{248}, \mathrm{Ser}^{249}, \mathrm{Ile}^{250}, \\
\mathrm{Asn}^{251}, \mathrm{Ile}^{313}, \mathrm{Pro}^{314}, \mathrm{Asp}^{339}, \\
\mathrm{Ala}^{342}\end{array}$ & -389.63 \\
\hline Isoquercitrin & -8.9 & $\begin{array}{l}\operatorname{Ser}^{9}(2.84), \operatorname{Arg}^{45}(3.15,2.42) \\
\operatorname{Ser}^{134}(3.02,3.11), \operatorname{Thr}^{138}(2.82) \\
\operatorname{Asn}^{251}(3.01), \operatorname{Thr}^{315}(2.77)\end{array}$ & $\begin{array}{c}\text { Arg }{ }^{48}, \mathrm{Met}^{49}, \mathrm{His}^{112}, \mathrm{Ala}^{135}, \\
\mathrm{Arg}^{136}, \mathrm{Ile}^{250}, \mathrm{Phe}^{253}, \mathrm{Met}^{310} \\
\mathrm{Ile}^{313}, \mathrm{Asp}^{339}, \mathrm{Ala}^{342}, \mathrm{Ala}^{346}, \\
\text { Vall }^{349}\end{array}$ & -333.32 \\
\hline Apocynin A & -8.8 & $\operatorname{Arg} 39(3.06,3.34)$ & $\begin{array}{l}\text { Arg }{ }^{45}, \operatorname{Arg}^{47}, \mathrm{Met}^{49}, \mathrm{Arg}^{109} \\
\mathrm{His}^{112}, \mathrm{Leu}^{130}, \mathrm{Ala}^{135} \\
\mathrm{Arg}^{136}, \mathrm{Il}^{313}, \mathrm{Thr}^{315}, \mathrm{Il}^{335} \\
\mathrm{Asp}^{339}, \mathrm{Ala}^{342}\end{array}$ & -350.35 \\
\hline Rotenone & -8.7 & $\begin{array}{c}\operatorname{Arg}^{109}(2.92), \operatorname{His}^{112}(3.01), \operatorname{Ser}^{134}(2.80) \\
\operatorname{Thr}^{315}(3.01)\end{array}$ & $\begin{array}{c}\text { Ser }^{9}, \mathrm{His}^{10}, \mathrm{Arg}^{45} \\
\mathrm{Ala}^{135}, \mathrm{Met}^{310}, \mathrm{Ile}^{313}, \operatorname{Pro}^{134}, \\
\mathrm{Asp}^{334}, \mathrm{Ala}^{342}, \mathrm{Ala}^{346}\end{array}$ & -305.07 \\
\hline Silybin & -8.6 & $\begin{array}{l}\operatorname{Arg}^{45}(2.97), \operatorname{Gly}^{111}(2.86), \operatorname{Ser}^{133}(2.98) \\
\operatorname{Ser}^{134}(2.98), \operatorname{Lys}^{311}(3.08), \operatorname{Asp}^{339}(2.73)\end{array}$ & $\begin{array}{l}\mathrm{His}^{112}, \mathrm{Ala}^{113}, \mathrm{Ala}^{135}, \mathrm{Val}^{248}, \mathrm{~S} \\
\mathrm{er}^{249}, \mathrm{Ile}^{250}, \mathrm{Asn}^{251}, \mathrm{Ala}^{252}, \mathrm{Ile}^{3} \\
{ }^{13}, \mathrm{Pro}^{314}, \mathrm{Ala}^{342}\end{array}$ & -381.76 \\
\hline Taspine & -8.6 & $\begin{array}{c}\operatorname{Arg}^{45}(2.80,3.30), \operatorname{His}^{112}(2.85) \\
\operatorname{Thr}^{315}(2.86)\end{array}$ & $\begin{array}{c}\mathrm{Arg}^{48}, \mathrm{Ala}^{135}, \mathrm{Thr}^{138}, \mathrm{Ile}^{250}, \mathrm{As} \\
\mathrm{n}^{251}, \mathrm{Ala}^{252}, \mathrm{Met}^{310}, \mathrm{Ile}^{313} \\
\mathrm{Pro}^{314}\end{array}$ & -297.38 \\
\hline Vicenin & -8.3 & $\begin{array}{l}\operatorname{Ser}^{9}(2.71), \operatorname{Arg}^{109}(2.74,3.38), \text { His }^{112} \\
\text { (3.22), } \operatorname{Ser}^{134}(3.0), \operatorname{Thr}^{315}(3.14)\end{array}$ & $\begin{array}{l}\mathrm{Asp}^{339}, \mathrm{Ala}^{342}, \mathrm{Ala}^{346}, \mathrm{Val}^{349} \\
\mathrm{Arg}^{48}, \mathrm{Met}^{49}, \mathrm{Leu}^{130}, \mathrm{Ala}^{135}, \\
\mathrm{Arg}^{136}, \mathrm{Met}^{310}, \mathrm{Ile}^{313}, \mathrm{Ile}^{335} \\
\quad \mathrm{Ala}^{342}, \mathrm{Ala}^{345}, \mathrm{Ala}^{346}\end{array}$ & -342.53 \\
\hline
\end{tabular}



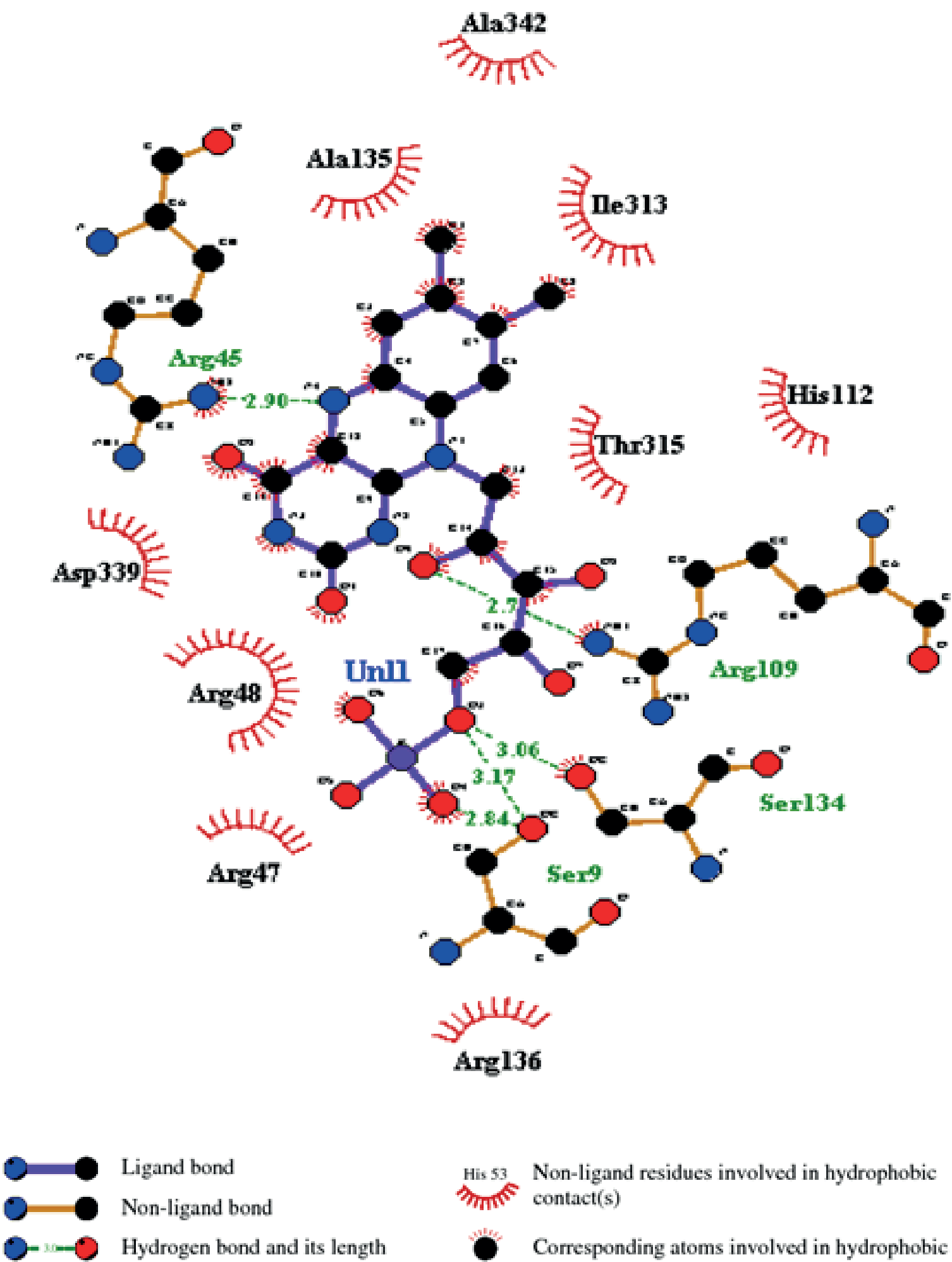

Ligand bond

Non-ligand bond

Hydrogen bond and its length
His 53 Non-ligand residues involved in hydrophobic $\eta_{\pi}$ s contact(s)

Corresponding atoms involved in hydrophobic contact(s)

Figure 5. Docking of FMN with the model, visualized by LIGPLOT ${ }^{(11)}$. 

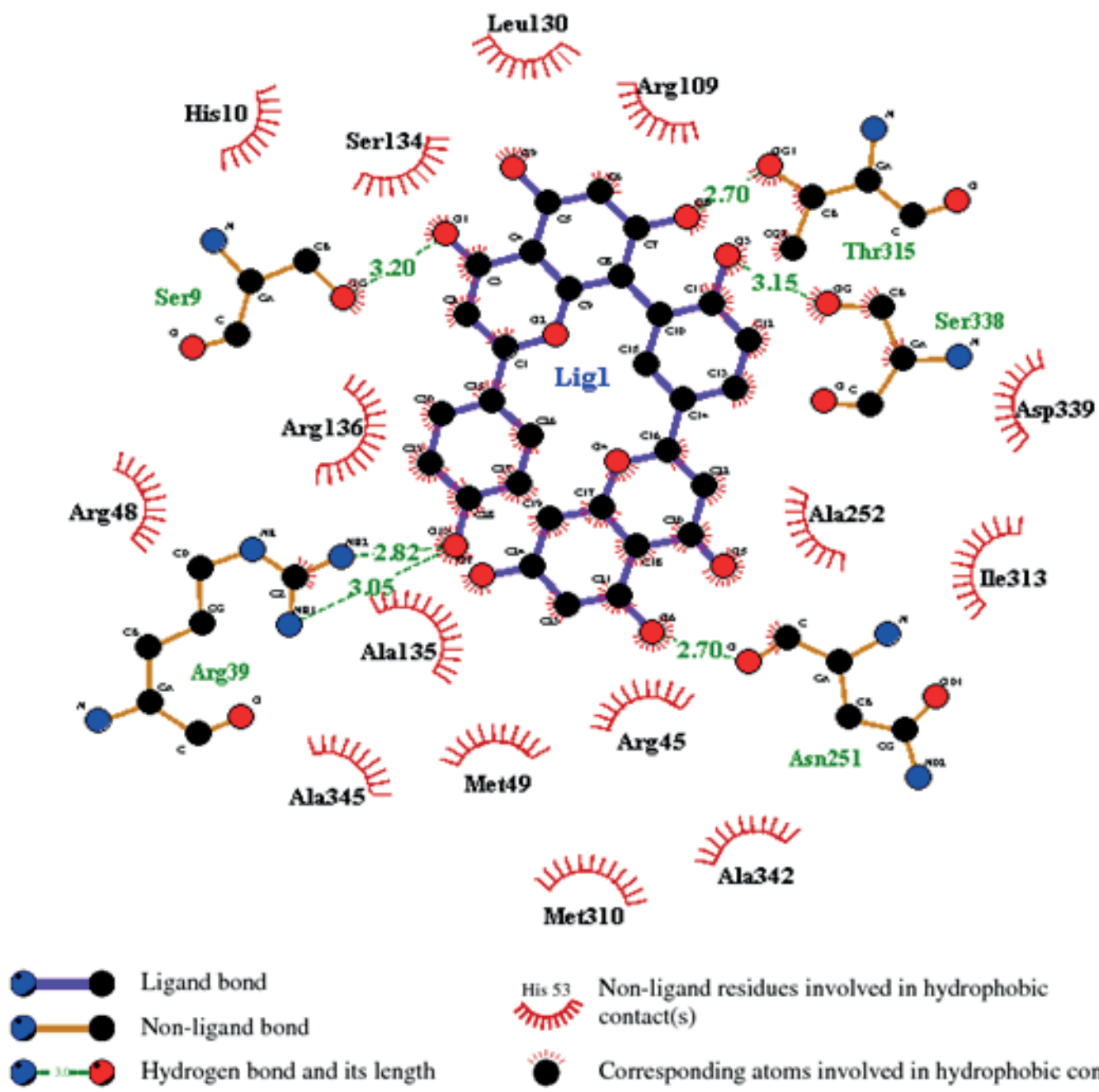

His 53 Non-ligand residues involved in hydrophobic $\eta \pi$ contact(s)

Corresponding atoms involved in hydrophobic contact(s)

Figure 6. Docking of amentoflavone with the model, visualized by LIGPLOT ${ }^{(11)}$.

Table 3. Physiochemical parameters of the ligands

\begin{tabular}{lcccccc}
\hline \multicolumn{1}{c}{ Compound } & ZINC data base ID & $\begin{array}{c}\mathbf{M} . \mathbf{W} \mathbf{t}^{\mathbf{1}} \\
\mathbf{( g / \mathbf { m o l } )}\end{array}$ & $\mathbf{x l o g} \mathbf{P}^{\mathbf{2}}$ & $\mathbf{H B D}^{\mathbf{3}}$ & $\mathbf{H B A}^{\mathbf{4}}$ & $\begin{array}{c}\mathbf{P S A}^{\mathbf{5}} \\
\mathbf{( A}^{\mathbf{0 2}} \mathbf{)}\end{array}$ \\
\hline Amentoflavone & ZINC03984030 & 538.464 & 5.61 & 6 & 10 & 182 \\
Scutellarin & ZINC21902916 & 461.355 & 0.07 & 6 & 12 & 210 \\
Rutin & ZINC59764511 & 610.521 & -1.06 & 10 & 16 & 269 \\
Hinokiflavone & ZINC04098521 & 538.464 & 5.18 & 5 & 10 & 170 \\
Isoquercitrin & ZINC04096845 & 464.379 & -0.36 & 8 & 12 & 211 \\
Apocynin A & ZINC14926814 & 468.414 & 1.56 & 7 & 10 & 177 \\
Rotenone & ZINC03860715 & 394.423 & 3.59 & 0 & 6 & 63 \\
Silybin & ZINC02033589 & 482.441 & 1.47 & 5 & 10 & 155 \\
Taspine & ZINC01702514 & 370.381 & 2.67 & 1 & 7 & 83 \\
Vicenin & ZINC98369451 & 594.522 & -2.10 & 11 & 15 & 271 \\
\hline
\end{tabular}

${ }^{1}$ Molecular weight, ${ }^{2}$ octanol/water partition coefficient, ${ }^{3}$ Hydrogen bond donors, ${ }^{4}$ hydrogen bond acceptors, ${ }^{5}$ polar surface area. 
Flavonoids are secondary products of plants present in vegetables and fruits with many medicinal proper-

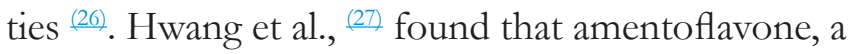
biflavonoid being extracted from Selaginella tamarisci$n a$, had an antimicrobial action against Gram positive and Gram negative microorganisms. The compound was active against Enterococcus faecium, S. aureus, Streptococcus mutans, Escherichia coli and Pseudomonas aeruginosa in a range from $4-36 \mu \mathrm{g} / \mathrm{ml}$. The study also suggested that amentoflavone also had a synergistic effect when combined with ampicillin, cefotaxime and chloramphenicol.

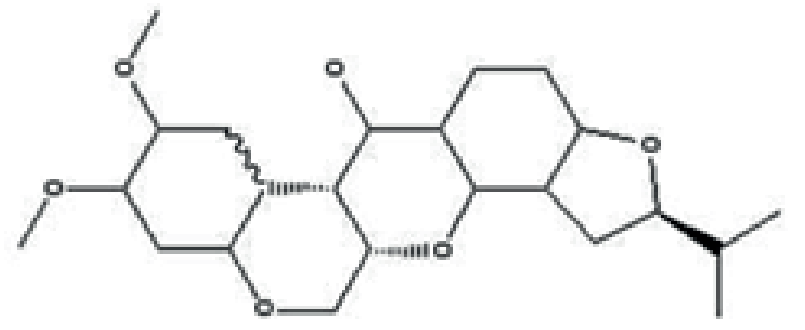

G

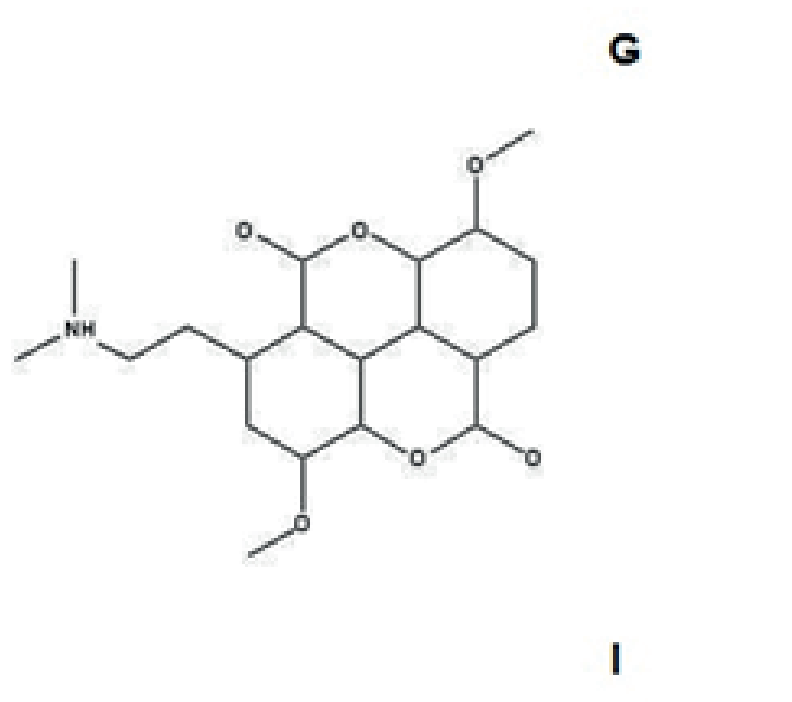

I
Hossain et al., $\stackrel{(28)}{\longrightarrow}$ used AutoDock 4.2 to screen ZINC database and obtained four compounds designated ZINC03803450, ZINC20149031, ZINC13387711 and ZINC16052528 that had strong binding affinities towards the active site of the enzyme where 5-enolpyruvyl shikimate-3-phosphate binds. In another approach, molecular docking studies on chorismate synthase of $S$. pneumoniae resulted in identification of four substrate analogs of 5-enoylpyruvyl shikimate-3-phosphate that had docking scores higher than the original compound $\stackrel{(29)}{\text {. }}$<smiles>COC1CC([C@H]2OC3CC([C@@H]4OC5CC(O)CC(O)C5C(O)[C@H]4O)CCC3O[C@@H]2CO)CCC1O</smiles>

H

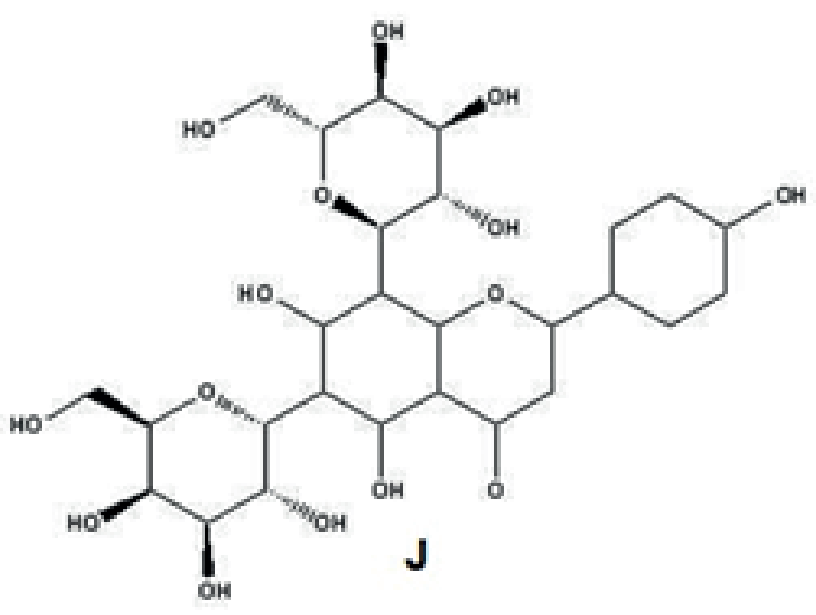

Figure 7. Chemical structure of ligands. (A) Amentoflavone, (B) scutellarin, (C) rutin, (D) Hinokiflavone, (E) isoquercitrin, (F) Apocynin A. 


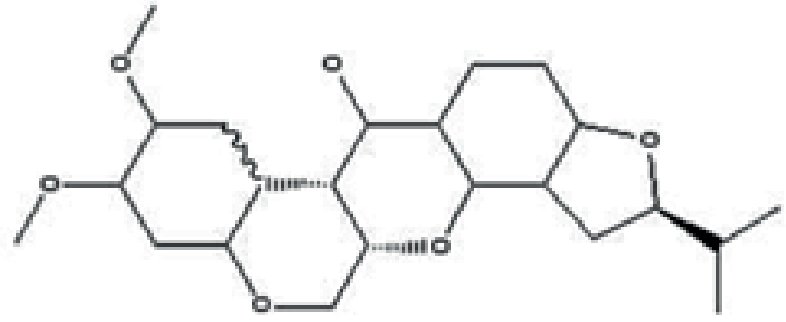

G

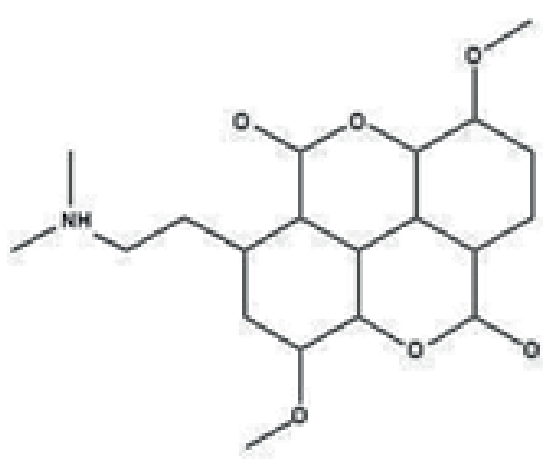

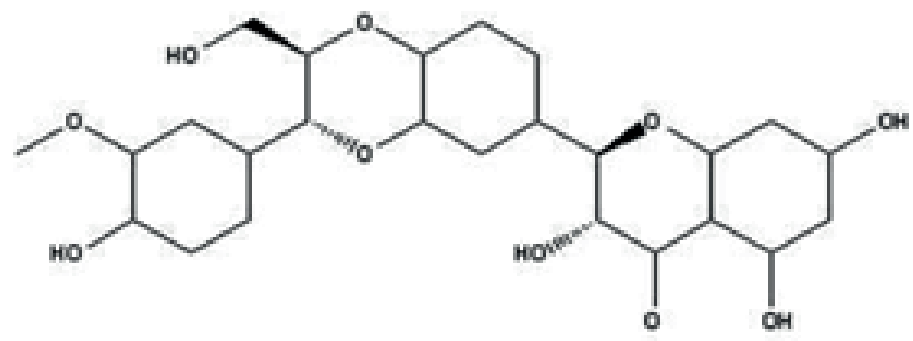

H

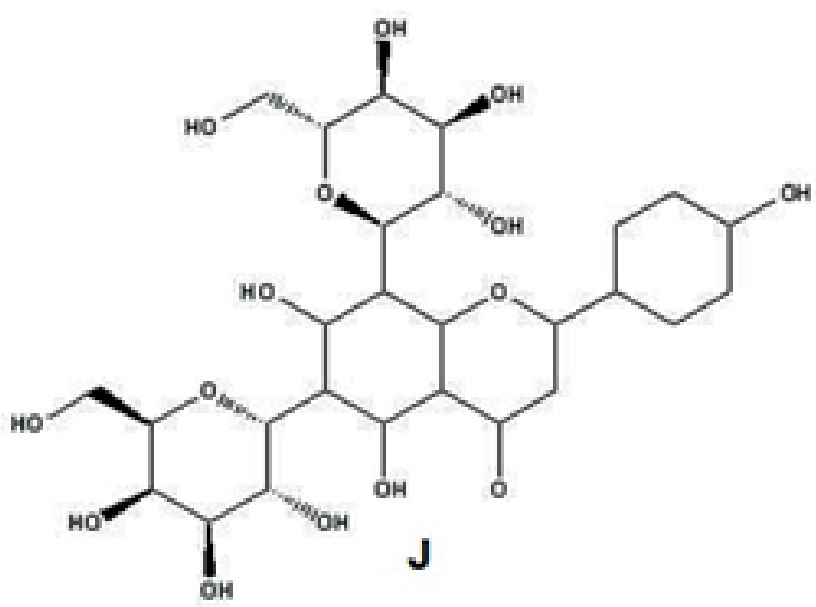

Figure 7. continued: $(\mathrm{G})$ rotenone, $(\mathrm{H})$ silybin, $(\mathrm{I})$ taspine, $(\mathrm{J})$ vicenin

Pharmacokinetics and toxicity profiles are presented in Table 4. Absorption through the digestive system is predicted by HIA and Caco-2 $\stackrel{(30)}{.}$. Except for scutellarin, all the ligands show high probability to be absorbed through intestine as predicted by HIA but only rotenone, silybin and taspine show a similar result in Caco-2. Predicting the permeability of a drug to pass through the blood-brain barrier is of importance in 2 aspects: (a) if the drug is required to exert an action in the central nervous system and (b) if the drug is acting on other organs and may have toxicity on the brain ${ }^{(31)}$. Only amentoflavone, hinokiflavone, rotenone and taspine may across the blood-brain barrier based on their predicted probabilities.

All ligands are subjected to transport by P-gp since their probabilities indicate that are substrates. However, rotenone inhibits P-gp I, hinokiflavone and silybin act as inhibitors to P-gp II and taspine may inhibit both P-gp I and II. These P-glycoproteins belong to ATP-binding cassette transporters found in cells of liver, kidney, intestine and blood-brain barrier as well, and function to export substances out from the cells. Thus, decrease the absorption of drugs from intestine while increase the elimination by liver through bile $\frac{(32,33,34)}{}$.

Cytochromes P450 are responsible for the oxidation step in metabolism of xenobiotics inside body including drugs. Hence, inhibition of these cytochromes would interfere with metabolism of other

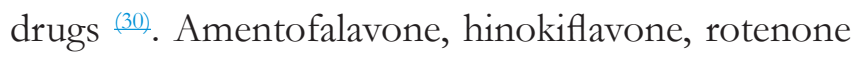
and silybin have a probability of such inhibition. All the compounds were non carcinogens and were not inhibitory to OCT2 which is involved in damage of kidney tissue due to accumulation of nephrotoxic substances $\stackrel{(35)}{ }$. Acute rat toxicity profiles showed that rotenone had the highest level among the natural products of $3.787 \mathrm{Mol} / \mathrm{Kg}$ and amentoflavone was second to rotenone in this regard. 
Table 4 A. SARadmet predicted ADMET profile

\begin{tabular}{cccccccc}
\hline Compound & $\begin{array}{c}\text { HIA } \\
\text { (Probability) }\end{array}$ & $\begin{array}{c}\text { BBB } \\
\text { (Probability) }\end{array}$ & $\begin{array}{c}\text { Caco-2 } \\
\text { (Probability) }\end{array}$ & $\begin{array}{c}\text { P-gp } \\
\text { Substrate } \\
\text { (Probability) }\end{array}$ & $\begin{array}{c}\text { P-gp I } \\
\text { Inhibitor } \\
\text { (Probability) }\end{array}$ & $\begin{array}{c}\text { P-gp II } \\
\text { Inhibitor } \\
\text { (Probability) }\end{array}$ & $\begin{array}{c}\text { OCT2 } \\
\text { Inhibitor } \\
\text { (Probability) }\end{array}$ \\
\hline Amentoflavone & $+(0.974)$ & $+(0.660)$ & $-(0.509)$ & $\mathrm{S}^{1}(0.500)$ & $\mathrm{N}^{2}(0.70)$ & $\mathrm{N}(0.775)$ & $\mathrm{N}(0.920)$ \\
Scutellarin & $-(0.805)$ & $-(0.596)$ & $-(0.873)$ & $\mathrm{S}(0.565)$ & $\mathrm{N}(0.942)$ & $\mathrm{N}(0.670)$ & $\mathrm{N}(0.945)$ \\
$\begin{array}{r}\text { Rutin } \\
\text { Hinokiflavone }\end{array}$ & $+(0.804)$ & $-(0.854)$ & $-(0.917)$ & $\mathrm{S}(0.690)$ & $\mathrm{N}(0.876)$ & $\mathrm{N}(0.855)$ & $\mathrm{N}(0.898)$ \\
Isoquercitrin & $+(0.956)$ & $+(0.659)$ & $-(0.731)$ & $\mathrm{S}(0.554)$ & $\mathrm{N}(0.748)$ & $\mathrm{I}^{3}(0.771)$ & $\mathrm{N}(0.918)$ \\
Apocynin A & $+(0.928)$ & $-(0.698)$ & $-(0.940)$ & $\mathrm{S}(0.591)$ & $\mathrm{N}(0.878)$ & $\mathrm{N}(0.797)$ & $\mathrm{N}(0.892)$ \\
Rotenone & $+(0.994)$ & $+(0.596)$ & $+(0.703)$ & $\mathrm{S}(0.587)$ & $\mathrm{N}(0.932)$ & $\mathrm{N}(0.985)$ & $\mathrm{N}(0.956)$ \\
Silybin & $+(0.970)$ & $-(0.768)$ & $+(0.581)$ & $\mathrm{S}(0.658)$ & $\mathrm{I}(0.958)$ & $\mathrm{N}(0.506)$ & $\mathrm{N}(0.736)$ \\
Taspin & $+(0.731)$ & $+(0.634)$ & $+(0.600)$ & $\mathrm{S}(0.806)$ & $\mathrm{I}(0.626)$ & $\mathrm{I}(0.680)$ & $\mathrm{N}(0.687)$ \\
Vicenin & $+(0.916)$ & $-(0.687)$ & $-(0.910)$ & $\mathrm{S}(0.628)$ & $\mathrm{N}(0.919)$ & $\mathrm{N}(0.887)$ & $\mathrm{N}(0.872)$ \\
\hline
\end{tabular}

${ }^{1} \mathrm{~S}$ : substrate, ${ }^{2} \mathrm{~N}$ : none, ${ }^{3} \mathrm{I}$ : inhibitor

Table 4 B. SARadmet predicted ADMET profile

\begin{tabular}{|c|c|c|c|c|c|c|c|c|}
\hline \multirow{2}{*}{$\begin{array}{l}\text { Compound } \\
\text { Amentoflavone }\end{array}$} & \multicolumn{2}{|c|}{$\begin{array}{c}\text { CYP } 450 \text { substrate } \\
\text { (Probability) }\end{array}$} & \multicolumn{4}{|c|}{ CYP 450 Inhibition (probability) } & \multirow{2}{*}{$\begin{array}{c}\begin{array}{c}\text { Carcinogen } \\
\text { (probability) }\end{array} \\
\mathrm{N}(0.931)\end{array}$} & \multirow{2}{*}{$\begin{array}{c}\begin{array}{c}\text { ART LD } \\
\text { (Mol/Kg) }\end{array} \\
3.130\end{array}$} \\
\hline & $\begin{array}{l}\text { CYP 2C9 } \\
\text { CYP 2D6 } \\
\text { CYP 3A4 }\end{array}$ & $\begin{array}{l}\mathrm{N}^{1}(0.793) \\
\mathrm{N}(0.907) \\
\mathrm{N}(0.715)\end{array}$ & $\begin{array}{l}\text { CYP 2C9 } \\
\text { CYP 2D6 } \\
\text { CYP 3A4 }\end{array}$ & $\begin{array}{c}\mathrm{I}^{2}(0.892) \\
\mathrm{N}(0.932) \\
\mathrm{I}(0.617)\end{array}$ & $\begin{array}{l}\text { CYP 1A2 } \\
\text { CYP 2C19 }\end{array}$ & $\begin{array}{l}\mathrm{I}(0.684) \\
\mathrm{I}(0.683)\end{array}$ & & \\
\hline Scutellarin & $\begin{array}{l}\text { CYP 2C9 } \\
\text { CYP 2D6 } \\
\text { CYP 3A4 }\end{array}$ & $\begin{array}{l}\mathrm{N}(0.821) \\
\mathrm{N}(0.908) \\
\mathrm{N}(0.684)\end{array}$ & $\begin{array}{l}\text { CYP 2C9 } \\
\text { CYP 2D6 } \\
\text { CYP 3A4 }\end{array}$ & $\begin{array}{l}\mathrm{N}(0.752) \\
\mathrm{N}(0.953) \\
\mathrm{N}(0.684)\end{array}$ & $\begin{array}{l}\text { CYP 1A2 } \\
\text { CYP 2C19 }\end{array}$ & $\begin{array}{l}\mathrm{N}(0.757) \\
\mathrm{N}(0.822)\end{array}$ & $\mathrm{N}(0.947)$ & 2.722 \\
\hline Rutin & $\begin{array}{l}\text { CYP 2C9 } \\
\text { CYP 2D6 } \\
\text { CYP 3A4 }\end{array}$ & $\begin{array}{l}\mathrm{N}(0.764) \\
\mathrm{N}(0.896) \\
\mathrm{N}(0.537)\end{array}$ & $\begin{array}{l}\text { CYP 2C9 } \\
\text { CYP 2D6 } \\
\text { CYP 3A4 }\end{array}$ & $\begin{array}{l}\mathrm{N}(0.907) \\
\mathrm{N}(0.955) \\
\mathrm{N}(0.925)\end{array}$ & $\begin{array}{l}\text { CYP 1A2 } \\
\text { CYP 2C19 }\end{array}$ & $\begin{array}{l}\mathrm{N}(0.867) \\
\mathrm{N}(0.903)\end{array}$ & $\mathrm{N}(0.961)$ & 2.498 \\
\hline Hinokiflavone & $\begin{array}{l}\text { CYP 2C9 } \\
\text { CYP 2D6 } \\
\text { CYP 3A4 }\end{array}$ & $\begin{array}{l}\mathrm{N}(0.812) \\
\mathrm{N}(0.911) \\
\mathrm{N}(0.682)\end{array}$ & $\begin{array}{l}\text { CYP 2C9 } \\
\text { CYP 2D6 } \\
\text { CYP 3A4 }\end{array}$ & $\begin{array}{c}\mathrm{I}(0.832) \\
\mathrm{N}(0.900) \\
\mathrm{I}(0.500)\end{array}$ & $\begin{array}{l}\text { CYP 1A2 } \\
\text { CYP 2C19 }\end{array}$ & $\begin{array}{l}\mathrm{I}(0.626) \\
\mathrm{I}(0.631)\end{array}$ & $\mathrm{N}(0.934)$ & 2.955 \\
\hline Isoquercitrin & $\begin{array}{l}\text { CYP 2C9 } \\
\text { CYP 2D6 } \\
\text { CYP 3A4 }\end{array}$ & $\begin{array}{l}\mathrm{N}(0.812) \\
\mathrm{N}(0.892) \\
\mathrm{N}(0.604)\end{array}$ & $\begin{array}{l}\text { CYP 2C9 } \\
\text { CYP 2D6 } \\
\text { CYP 3A4 }\end{array}$ & $\begin{array}{l}\mathrm{N}(0.930) \\
\mathrm{N}(0.951) \\
\mathrm{N}(0.919)\end{array}$ & $\begin{array}{l}\text { CYP 1A2 } \\
\text { CYP 2C19 }\end{array}$ & $\begin{array}{l}\mathrm{N}(0.908) \\
\mathrm{N}(0.930)\end{array}$ & $\mathrm{N}(0.960)$ & 2.387 \\
\hline Apocynin A & $\begin{array}{l}\text { CYP 2C9 } \\
\text { CYP 2D6 } \\
\text { CYP 3A4 }\end{array}$ & $\begin{array}{l}\mathrm{N}(0.833) \\
\mathrm{N}(0.900) \\
\mathrm{N}(0.653)\end{array}$ & $\begin{array}{l}\text { CYP 2C9 } \\
\text { CYP 2D6 } \\
\text { CYP 3A4 }\end{array}$ & $\begin{array}{l}\mathrm{N}(0.954) \\
\mathrm{N}(0.957) \\
\mathrm{N}(0.828)\end{array}$ & $\begin{array}{l}\text { CYP 1A2 } \\
\text { CYP 2C19 }\end{array}$ & $\begin{array}{l}\mathrm{N}(0.957) \\
\mathrm{N}(0.961)\end{array}$ & $\mathrm{N}(0.964)$ & 2.325 \\
\hline Rotenone & $\begin{array}{l}\text { CYP 2C9 } \\
\text { CYP 2D6 } \\
\text { CYP 3A4 }\end{array}$ & $\begin{array}{l}\mathrm{N}(0.861) \\
\mathrm{N}(0.853) \\
\mathrm{S}^{4}(0.646)\end{array}$ & $\begin{array}{l}\text { CYP 2C9 } \\
\text { CYP 2D6 } \\
\text { CYP 3A4 }\end{array}$ & $\begin{array}{c}\mathrm{N}(0.769) \\
\mathrm{N}(0.923) \\
\mathrm{I}(0.796)\end{array}$ & $\begin{array}{l}\text { CYP 1A2 } \\
\text { CYP 2C19 }\end{array}$ & $\begin{array}{l}\mathrm{I}(0.911) \\
\mathrm{I}(0.899)\end{array}$ & $\mathrm{N}(0.941)$ & 3.787 \\
\hline Silybin & $\begin{array}{l}\text { CYP 2C9 } \\
\text { CYP 2D6 } \\
\text { CYP 3A4 }\end{array}$ & $\begin{array}{l}\mathrm{N}(0.761) \\
\mathrm{N}(0.874) \\
\mathrm{N}(0.550)\end{array}$ & $\begin{array}{l}\text { CYP 2C9 } \\
\text { CYP 2D6 } \\
\text { CYP 3A4 }\end{array}$ & $\begin{array}{c}\mathrm{I}(0.635) \\
\mathrm{N}(0.923) \\
\mathrm{N}(0.550)\end{array}$ & $\begin{array}{l}\text { CYP 1A2 } \\
\text { CYP 2C19 }\end{array}$ & $\begin{array}{l}\mathrm{N}(0.771) \\
\mathrm{N}(0.599)\end{array}$ & $\mathrm{N}(0.939)$ & 2.221 \\
\hline Taspine & $\begin{array}{l}\text { CYP 2C9 } \\
\text { CYP 2D6 } \\
\text { CYP } 3 A 4\end{array}$ & $\begin{array}{c}\mathrm{N}(0.809) \\
\mathrm{N}(0.694) \\
\mathrm{S}(0.672)\end{array}$ & $\begin{array}{l}\text { CYP 2C9 } \\
\text { CYP 2D6 } \\
\text { CYP 3A4 }\end{array}$ & $\begin{array}{l}\mathrm{N}(0.806) \\
\mathrm{N}(0.828) \\
\mathrm{N}(0.911)\end{array}$ & $\begin{array}{l}\text { CYP 1A2 } \\
\text { CYP 2C19 }\end{array}$ & $\begin{array}{l}\mathrm{N}(0.565) \\
\mathrm{N}(0.870)\end{array}$ & $\mathrm{N}(0.821)$ & 2.549 \\
\hline Vicenin & $\begin{array}{l}\text { CYP 2C9 } \\
\text { CYP 2D6 } \\
\text { CYP 3A4 }\end{array}$ & $\begin{array}{l}\mathrm{N}(0.812) \\
\mathrm{N}(0.871) \\
\mathrm{N}(0.617)\end{array}$ & $\begin{array}{l}\text { CYP 2C9 } \\
\text { CYP 2D6 } \\
\text { CYP } 3 \mathrm{~A} 4\end{array}$ & $\begin{array}{l}\mathrm{N}(0.918) \\
\mathrm{N}(0.945) \\
\mathrm{N}(0.876)\end{array}$ & $\begin{array}{l}\text { CYP 1A2 } \\
\text { CYP 2C19 }\end{array}$ & $\begin{array}{l}\mathrm{N}(0.880) \\
\mathrm{N}(0.910)\end{array}$ & $\mathrm{N}(0.948)$ & 2.200 \\
\hline
\end{tabular}

${ }^{1} \mathrm{~N}$ : none, ${ }^{2} \mathrm{I}$ : inhibitor, ${ }^{3} \mathrm{~W}$ : weak inhibitor, ${ }^{4} \mathrm{~S}$ : substrate 


\section{CONCLUSIONS}

Homology modeling and molecular docking reduces cost, time and effort as initial step in screening for new medicines. However, this step should be accompanied by studying pharmacodynamics and pharmacokinetics to provide information about interactions of lead compounds inside the human body as well as co-administered drugs. Antibiotic research may exploit alternative targets in bacteria such as chorismate synthase and other enzymes of the shikimate pathway on which compounds are screened from chemical libraries to identify inhibitors.

\section{ACKNOWLEDGEMENTS}

The author would like to thank Dr. Roman Laskowski for free providing of LIGPLOT+.

\section{REFERENCES}

1. Yarwood JM, Schlievert PM. Quorum sensing in Staphylococcus infections. J Clin Invest. 2003. 112: 1620-25. https://doi.org/10.1172/JCI20442

2. Tong SY, Davis JS, Eichenberger E, Holland TL, Flower Jr VG. Staphylococcus aureus infections: Epidemiology, pathophysiology, clinical manifestations, and management. Clin Microbiol Rev. 2015. 28:603-61.

https://doi.org/10.1128/CMR.00134-14

3. Kaneko J, kamio Y. Bacterial two-component and hetero-heptameric pore-forming cytolytic toxins: structures pore-forming mechanism organization of the genes. Biosci Biotechnol Biochem. 2004. 68:981-03. https://doi.org/10.1271/bbb.68.981

4. Boswihi SS, Udo EE. Methicillin-resistant Staphylococcus aureus: an update on the epidemiology, treatment options and infection control. Curr Med Res Prac. 2018. 8:18-24.

https://doi.org/10.1016/i.cmrp.2018.01.001

5. Al-Dahbi AM, Al-Mathkhury HJ. Distribution of methicillin resistant Staphylococcus aureus in Iraqi patients and healthcare workers. Iraqi J Sci.2013. 54(2):293-300.

6. Dias MV, Ely F, Palma MS, de Azevedo WFJr., Basso LA, Santos DS. Chorismate synthase: An attractive target for drug development against orphan diseases. Curr Drug Targets. 2007. 8(3): 437-44. https://doi.org/10.2174/138945007780058924
7. Macheroux P, Schmid J, Amrhein N, Schaller A. 1999. A unique reaction in a common pathway: mechanism and function of chorismate synthase in the shikimate pathway. Planta. 1999: 207:32534. https://doi.org/10.1007/s004250050489

8. González-Bello C. Inhibition of shikimate kinase and type II dehydroquinase for antibiotic discovery: Structure-based design and simulation studies. Curr Topics Med Chem. 2016. 16:960-77.

https://doi.org/10.2174/1568026615666150825 142527

9. Holden MT, Feil EJ, Lindsay JA, Peacock SJ, Day NP, Enright MC, et al. Complete genomes of two clinical Staphylococcus aureus strains: Evidence for the rapid evolution of virulence and drug resistance. Proc Nat Acad Sci. USA. 2004. 101(26): 9786-91.

10. Källberg M, Wang H, Wang S, Peng J, Wang Z, Lu $\mathrm{H}$, et al. Template-based protein structure modeling using the RaptorX web server. Nat Protocols. 2012. 7:1511-22.

https://doi.org/10.1038/nprot.2012.085

11. Wallace AC, Laskowaski RA, Thornton JM. LIGPLOT: A program to generate schematic diagrams of protein-ligand interactions. Protein Eng. 1996. 8:127-34.

https://doi.org/10.1093/protein/8.2.127

12. Waterhouse A, Bertoni M, Bienert S, Studer G, Tauriella G, Gumienny R, et al. SWISS-MODEL: Homology modeling of protein and protein structures and complexes. Nucleic Acid Res. 2018. 46:W296-03.

https://doi.org/10.1093/nar/gky427

13. Colovos C, Yeates TO. Verification of protein structures: Patterns of non-bonded atomic interactions. Protein Sci. 1993. 2:1511-19.

https://doi.org/10.1002/pro.5560020916

14. Wiederstein M, Sippl MJ. ProSA-web: Interactive web service for the recognition of errors in three-dimensional structures of proteins. Nucleic Acids Res. 2007. 35:W407-10.

https://doi.org/10.1093/nar/gkm290

15.Lovell SC, Davis IW, Arendall WB 3rd, de Bakker PI, Word JM, Prisant MG, et al. Structure validation by $\mathrm{C} \alpha$ geometry: phi, psi and $\mathrm{C} \beta$ deviation. Proteins. 2003. 50(3):437-50.

https://doi.org/10.1002/prot.10286 
16. Chen VB, Arendall WB 3rd, Headd JJ, Keedy DA, Immormino RM, Kapral GJ, et al. MolProbity: all atom structure validation for macromolecular crystallography. Acta cryst. 2010. D66:12-21. https://doi.org/10.1107/S0907444909042073

17. Irwin JJ, Shoichet. ZINC: A free database of commercially available compounds for virtual screening. J Chem Inf Model. 2005. 45:177-82. https://doi.org/10.1021/ci049714+

18. Trott O, Olson AJ. AutoDock Vina: improving the speed and accuracy of docking with a new scoring function, efficient optimization and multithreading. J Comput Chem. 2010. 31:455-61. https://doi.org/10.1002/jcc.21334

19. Cheng F, Li W, Zhou Y, Shen J, Wu Z, Liu G, et al. admetSAR: A comprehensive source and free tool for evaluating chemical ADMET properties. J Chem Inf Model. 2012. 52(11):3099-05. https://doi.org/10.1021/ci300367a

20. Maclean J, Ali S. The structure of chorismate synthase reveals a novel flavin binding site fundamental to a unique chemical reaction. Structure. 2003. 11:1499-11.

\section{https://doi.org/10.1016/j.str.2003.11.005}

21. Sanner MF. Python: A programming language for software integration and development. J Mol Graphics Mod.1999. 17:57-61.

22.Laskowski RA, MacArthur MW, Moss D and Thornton JM .1993. PROCHECK: A program to check the stereochemical quality of protein structures. J Appl Crystal. 1993. 26:283-91. https://doi.org/10.1107/S0021889892009944

23. Kelder J, Grootenhuis PDJ, Bayada DM, Delbressine LPC, Ploemen J-P. Polar molecular surface as a dominating determinant for oral absorption and brain penetration of drugs. Pharm Res. 1999. 16: 1514-19.

https://doi.org/10.1023/A:1015040217741

24. Navia M, Chaturvedi PR. Design principles for orally bioavailable drugs. Drug Discov Today. 1:179-89.

https://doi.org/10.1016/1359-6446(96)10020-9

25.Lipinski CA, Lombardo F, Dominy BW, Feeney P. Experimental and computational approaches to estimate solubility and permeability in drug discovery and development settings. Adv Drug Deliv Rev. 2001. 46:3-26.
26. Panche AN, Diwan AD, Chandra SR. Flavonoids: an overview. J Nutritional Sci. 2016. 5(e47):1-15. https://doi.org/10.1017/ins.2016.41

27. Hwang JH, Choi H, Woo E-R, Lee DG. Antibacterial effect of amentoflavone and its synergistic effect with antibiotics. J. Microbiol. Biotechnol. 2013. 23(7): 953-58. https://doi.org/10.4014/jmb.1302.02045

28. Hossain MM, Roy PK, Jannatul Mosnaz ATM, Shakil SK, Hasan MM, Prodhan SH. Structural analysis and molecular docking of potential ligands with chorismate synthase of Listeria monocytogenes: A novel antibacterial drug target. Indian J Bioch Bioph 2015. 52:45-49.

29. Kolawole OC. Design and docking studies of inhibitors for the chorismate synthase from Streptococcus pneumoniae using 5-enolpyruvylshikimate-3-phosphate (EPSP) analogues. J Pharma Bioresource. 2015. 12(1):60-76.

https://doi.org/10.4314/jpb.v12i1.9

30.de la Nuez A, Rodríguez R. Current methodology for the assessment of ADME-Tox properties on drug candidate molecules. Biotec Aplic. 2008. 25(2):97-10.

31. Carpenter TS, Kirshner DA, Lau EY, Wong SE, Nilmeier JP, Lightstone FC. A method to predict blood-brain barrier permeability of drug-like compounds using molecular dynamics simulations. Biophysical J. 2014. 107:630-41.

https://doi.org/10.1016/i.bpj.2014.06.024

32.Lin JH, Yamazaki M. Role of P-glycoprotein in pharmacokinetics. Clin Pharmacokint. 2003. 42(1): 59-98.

https://doi.org/10.2165/00003088-200342010$\underline{00003}$

33.Sharom FJ. ABC multidrug transporters: Structure, function and role in chemoresistance. Cancer Biol Ther. 2008. 3:382-84.

34. Colabufo NA, Berardi F, Cantore M, Contino M, Inglese C, Niso M, et al. Perspectives of P-glycoprotein modulating agents in oncology and neurodegenerative diseases: pharmaceutical, biological, and diagnostic potentials. J Med Chem. 2010. 53(5): 1883-97.

https://doi.org/10.1021/jm900743c

35. Hagos Y, Wolff NA. Assessment of the role of renal organic anion transporters in drug-induced nephrotoxicity. Toxins. 2010. 2: 2055-82. https://doi.org/10.3390/toxins2082055 